\title{
Analysis of the birch pollen seasons in the selected Polish cities in 2020
}

\author{
Monika Ziemianin', Dorota Myszkowska', Małgorzata Puc², Agnieszka Lipiec ${ }^{3}$, Małgorzata Malkiewicz, \\ Krystyna Piotrowska-Weryszko ${ }^{5}$, Kazimiera Chłopek ${ }^{6}$, Grzegorz Siergiejko ${ }^{7}$, Ewa Kalinowska ${ }^{8}$, \\ Dariusz Jurkiewicz ${ }^{9}$, Andrzej Wieczorkiewicz ${ }^{8}$, Piotr Rapiejko ${ }^{8,9}$ \\ ${ }^{1}$ Department of Clinical and Environmental Allergology, Medical College, Jagiellonian University, Cracow, Poland \\ ${ }^{2}$ Institute of Marine \& Environmental Sciences, University of Szczecin, Poland \\ ${ }^{3}$ Department of Prevention of Environmental Hazards and Allergology, Medical University of Warsaw, Poland \\ ${ }^{4}$ Laboratory of Paleobotany, Department of Stratigraphical Geology, Institute of Geological Sciences, \\ University of Wroclaw, Wroclaw, Poland \\ ${ }^{5}$ Department of Botany and Plant Physiology, University of Life Sciences in Lublin, Poland \\ ${ }^{6}$ Faculty of Natural Sciences, Institute of Earth Sciences, University of Silesia in Katowice, Poland \\ ${ }^{7}$ Pediatrics, Gastroenterology and Allergology Department, University Children Hospital, \\ Medical University of Bialystok, Poland \\ ${ }^{8}$ Allergen Research Center, Warsaw, Poland \\ ${ }^{9}$ Department of Otolaryngology with Division of Cranio-Maxillo-Facial Surgery in Military Institute of Medicine, \\ Warsaw, Poland
}

\begin{abstract}
:
The aim of the study was to compare the birch pollen seasons in selected 12 cities in Poland in 2020. The volumetric method of sampling was used to collect pollen samples. The estimation of the seasonal parameters was based on descriptive statistics. The clear differences among SPIn values at all sites were recorded. The lowest value was recorded in Bialystok (1.863 pollen $\left./ \mathrm{m}^{3}\right)$, whereas the highest one in Lublin $\left(16.253 \mathrm{pollen} / \mathrm{m}^{3}\right)$. The thermal conditions in the north-eastern part of Poland were the least favourable for birch pollen seasons.
\end{abstract}

Key words: birch, pollen concentrations, allergy, 2020

\section{Introduction}

The genus Betula belongs to the Betulaceae family wide-spread in Europe, particularly in northern regions [1]. Betula pendula is the most among native birches, it occurs mainly on fairly fertile, light, well-drained soils, particularly when soil conditions are acidic. Betula pubescens is less common than $B$. pendula and grows on wetland, swampy and peaty soils. In Poland, two main birch species are the most common: Betula pendula Roth and Betula pubescens Ehrh. [2], occurring almost in the whole country [3].

The birch pollen season begins at the end of March in Western Europe, from the beginning to mid-
-April in Central and Eastern Europe and from late April to late May in Northern Europe [4]. The duration of the main season is remarkably dependent on temperature and thus varies from 2 to as much as 8 weeks [5]. B. pendula starts to bloom from the second half of April to the end of May, while $B$. pubescens starts about two weeks later than $B$. pendula. Birch trees produce a large amount of pollen (5.5 million pollen grains per the male inflorescence), their pollen seasons are short, but intensive [6-8], the total pollen amount contains pollen originating from both Betula species.

Birch pollen is highly allergenic and causes inhalation allergy in Northern and Central Europe, in- 
cluding Poland. The common occurrence of birches in Poland and allergenic features of their pollen make birch the main source of tree pollen allergens provoking allergy symptoms in spring [6]. In Poland, allergy to birch pollen makes up to $50 \%$ of tree pollen allergies. Moreover, $10-15 \%$ of people with pollen allergy are monosensitive to birch pollen allergens [9-11].

The main birch pollen allergen, Bet v1, belonging to the pathogenesis-related family (PR-10), is recognized by the specific IgE in $95 \%$ of sensitive patients [12], and is responsible not only for typical symptoms of the respiratory tract disease, but also can provoke cross-reactions with different food (row fruits, vegetables among others) due to the great similarity of the PR-10 allergen structures [13].

\section{Aim}

The aim of the study was to compare the birch pollen seasons in selected 12 cities in Poland in 2020.

\section{Materials and methods}

The birch pollen seasons were analyzed in the following Polish cities: Szczecin, Zielona Gora, Olsztyn, Bialystok, Warsaw, Bydgoszcz, Piotrkow Trybunalski, Wroclaw, Opole, Cracow, Lublin and Sosnowiec. Birch pollen concentration was determined by the volumetric method using a Hirst type samplers. All procedures are in accordance with the recommendations of the European Aerobiology Society $[14,15]$. Microscopic observations were performed in a 7 day cycle with assessment of 24-hour periods. Daily average pollen concentrations were expressed as the number of pollen grains in $1 \mathrm{~m}^{3}$ of air (pollen $\left./ \mathrm{m}^{3}\right)$. On the basis of the daily pollen concentrations, the start and the end of pollen seasons were calculated by the combined percentage methods (95\% and $98 \%$, respectively), the maximum daily concentration and annual pollen sum (SPIn, seasonal pollen integral) were also determined. The season characteristics were analyzed using the descriptive statistics (Statistica 13), while the pollen season dynamics was presented on the graphs (fig. 1-6).

\section{Results}

The basic characteristics of the pollen seasons are presented in table 1 . It was found that at 11 study sites, the birch pollen seasons began in the first decade of April, with the exception of Olsztyn, where the season started on April $11^{\text {th }}$. The beginning of the season is characterized by the lowest variability $(\mathrm{V} \%=1.76)$, while the season end was a bit higher $(\mathrm{V} \%=6.25)$. The longest birch pollen season was observed in Bialystok, it lasted up to 45 days, while the shortest one was noted in Cracow, where it lasted 21 days. The average duration of the pollen season at the 12 studied sites is 26 days. Seasonal pollen integral clearly differed among the study sites $(\mathrm{CV} \%=44.30)$. The lowest value was recorded in Bialystok (1.863 pollen $\left./ \mathrm{m}^{3}\right)$, whereas the highest in Lublin (16.253 pollen $/ \mathrm{m}^{3}$ ), similarly as in 2019 [16]. It was similar to the maximum daily concentration, which was about 17 times higher in Lublin than in Bialystok. The maximum concentration of pollen at majority of sites was recorded on April $12^{\text {th }}$ and $13^{\text {th }}$, only in Olsztyn maximum concentration occurred on April $17^{\text {th }}$ and in Bialystok on April 24 $4^{\text {th }}$. The dynamics of the birch pollen season was presented on the graphs (fig. 1-6), showing a characteristic peak values related to the maximum concentration within the season.

\section{Discussion}

Birch pollen seasons in Poland, in 2020 were rather dense with one, evident peak day. The season curve was asymmetric, right-skewed, pollen concentration increased rapidly at all the study sites. Pollen season dynamics was typical for birch pollen behaviour, as it was observed in the previous years, in different regions of Poland [6-11].

It should be stressed that the seasons started almost at the same time at all study sites, the differences occurred up to 1-3 days only. It is stated that the thermal conditions before the pollen season determined the pollination of birches [8, 17-20]. According to the Monthly Climate Monitoring Bulletin, published by the Institute of Meteorology and Water Management - National Research Institute [21], air temperature in March 2020 was higher than the mean values in 1981-2010 (the reference period). In southern and western parts of Poland, mean monthly temperature was around $5^{\circ} \mathrm{C}$, in the other regions was around $4^{\circ} \mathrm{C}$, so this month was classified as "very warm", i.e. with the temperature range of 0.8-0.9 percentile in most parts of Poland, and in the coastal strip of the Baltic Sea even as "anomalously warm" (0.9-0.95 percentile). Such high air temperature in early spring, contributed to the development of vegetation, including the early flowering of birches almost in the whole of Poland, the earliest in Szczecin, and a few days later from the south-western to the north-eastern part of the country. However, it must be stressed, that the first week of April is time 
Table 1. Descriptive statistics of birch pollen season characteristics in the selected Polish cities, in 2020.

\begin{tabular}{|c|c|c|c|c|c|c|c|}
\hline City/monitoring site & $\begin{array}{l}\text { Pollen season } \\
\text { range }(98 / 95 \%)\end{array}$ & $\begin{array}{l}\text { Season start } \\
\qquad(98 \%)^{1}\end{array}$ & $\begin{array}{l}\text { Season end } \\
(95 \%)^{1}\end{array}$ & $\begin{array}{l}\text { Season } \\
\text { duration }^{2}\end{array}$ & Peak value ${ }^{3}$ & $\begin{array}{l}\text { Date of peak } \\
\text { value }^{1}\end{array}$ & $\mathrm{SPIn}^{4}$ \\
\hline Bialystok & $9.04-23.05$ & 100 & 144 & 45 & 324 & 119 & 1863 \\
\hline Bydgoszcz & $7.04-30.04$ & 98 & 121 & 24 & 985 & 104 & 6811 \\
\hline Cracow & $7.04-27.04$ & 98 & 118 & 21 & 1432 & 104 & 9173 \\
\hline Sosnowiec & $7.04-30.04$ & 98 & 121 & 24 & 1732 & 104 & 5139 \\
\hline Lublin & $8.04-29.04$ & 99 & 120 & 22 & 5530 & 104 & 16253 \\
\hline Olsztyn & $11.04-11.05$ & 102 & 132 & 31 & 1212 & 108 & 8738 \\
\hline Opole & $6.04-29.04$ & 97 & 120 & 24 & 1376 & 103 & 9393 \\
\hline Piotrkow Trybunalski & $7.04-29.04$ & 98 & 120 & 23 & 2432 & 104 & 10555 \\
\hline Szczecin & $4.04-28.04$ & 95 & 119 & 25 & 748 & 103 & 4076 \\
\hline Warsaw & $7.04-29.04$ & 98 & 120 & 23 & 1786 & 104 & 10443 \\
\hline Wroclaw & $6.04-27.04$ & 97 & 118 & 22 & 2123 & 103 & 7651 \\
\hline Zielona Gora & $6.04-28.04$ & 97 & 119 & 23 & 1879 & 103 & 10478 \\
\hline \multicolumn{2}{|l|}{ Maximum min } & 102.0 & 144.0 & 45.0 & 5530 & 119 & 16253.0 \\
\hline \multicolumn{2}{|l|}{ Minimum max } & 95.0 & 118.0 & 21.0 & 324 & 103 & 1863.0 \\
\hline \multicolumn{2}{|l|}{ Arithmetic average $x$} & 98.08 & 122.67 & 25.58 & 1797 & 105 & 8381.08 \\
\hline \multicolumn{2}{|c|}{ Standard deviation $s$} & 1.73 & 7.67 & 6.61 & 1315.57 & 4.54 & 3712.98 \\
\hline \multicolumn{2}{|l|}{ Median me } & 98.0 & 120.0 & 23.5 & 1582 & 104 & 8955.5 \\
\hline \multicolumn{2}{|c|}{ Coefficient of variation (CV\%) } & 1.76 & 6.25 & 25.85 & 73.23 & 4.31 & 44.30 \\
\hline \multicolumn{2}{|c|}{$\begin{array}{l}95 \% \text { confidence interval } \\
{[-95 \% ;+95 \%]}\end{array}$} & $97.9 ; 99.2$ & $\begin{array}{r}117.8 .0 \\
127.5\end{array}$ & $21.4 ; 29.8$ & $\begin{array}{l}960.71 \\
2632.46\end{array}$ & $\begin{array}{r}102 \\
108\end{array}$ & $\begin{array}{r}6022.0 \\
10740.2\end{array}$ \\
\hline
\end{tabular}

${ }^{1}$ Consecutive day from the January $1^{\text {st: } ;}$ number of days; ${ }^{3}$ maximum daily pollen concentration expressed as pollen $/ \mathrm{m}^{3 ;} ;{ }^{4}$ seasonal pollen integral expressed as $\left(\mathrm{pollen}{ }^{*}\right.$ day $\left./ \mathrm{m}^{3}\right):$ sum of daily pollen concentrations obtained in the season, calculated by the $98 / 95 \%$ methods.

Figure 1. Birch pollen concentration in Cracow and Sosnowiec in 2020.

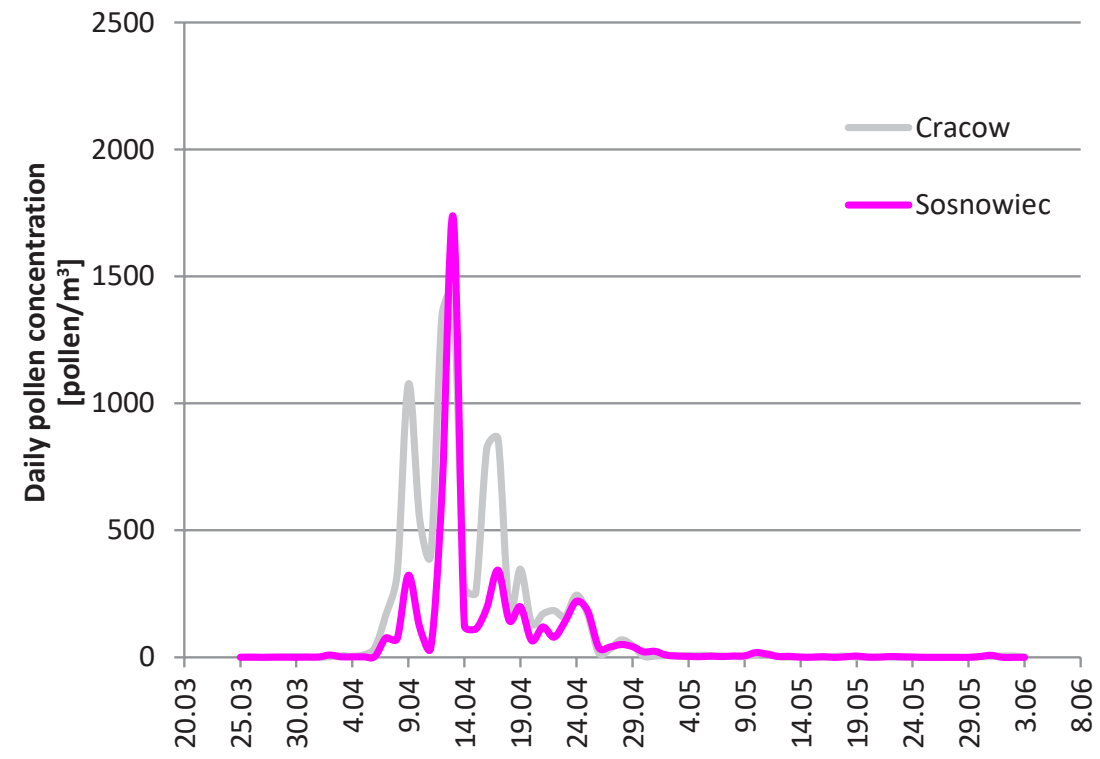
https://www.journalsmededu.pl/index.php/alergoprofil: 26.04.2023; 13:33,55 
Figure 2. Birch pollen concentration in Opole and Wroclaw in 2020.

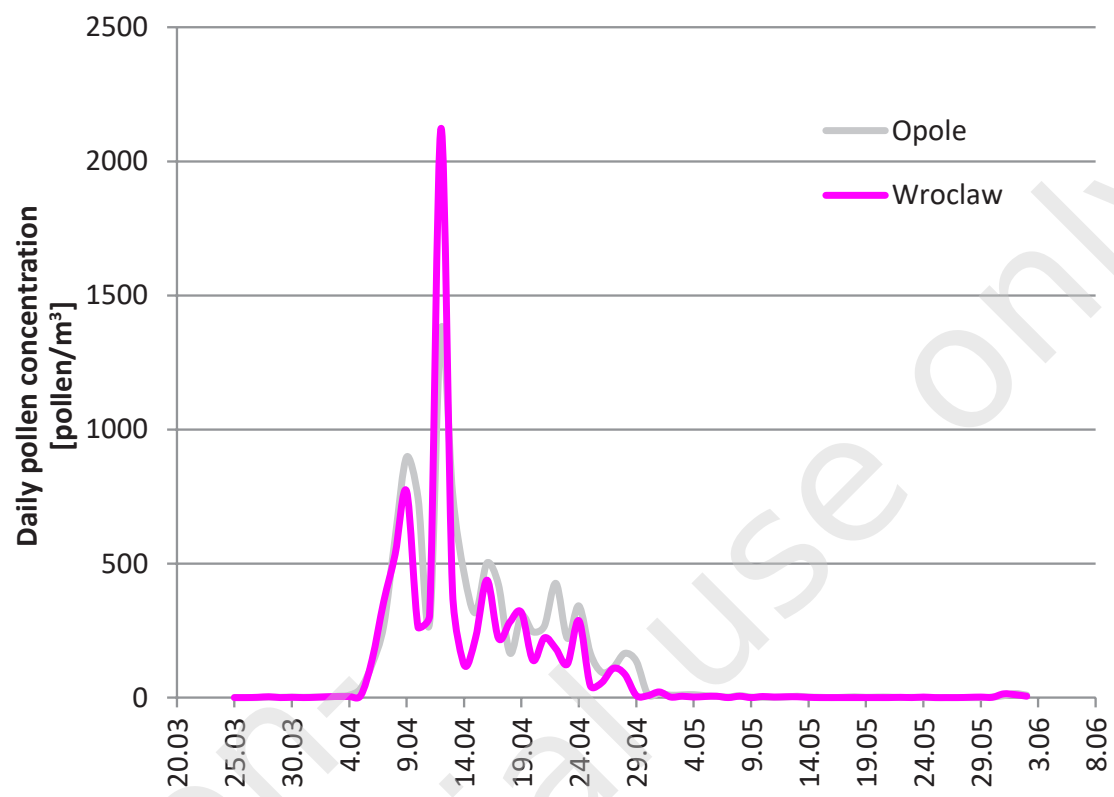

Figure 3. Birch pollen concentration in Lublin and Warsaw in 2020.

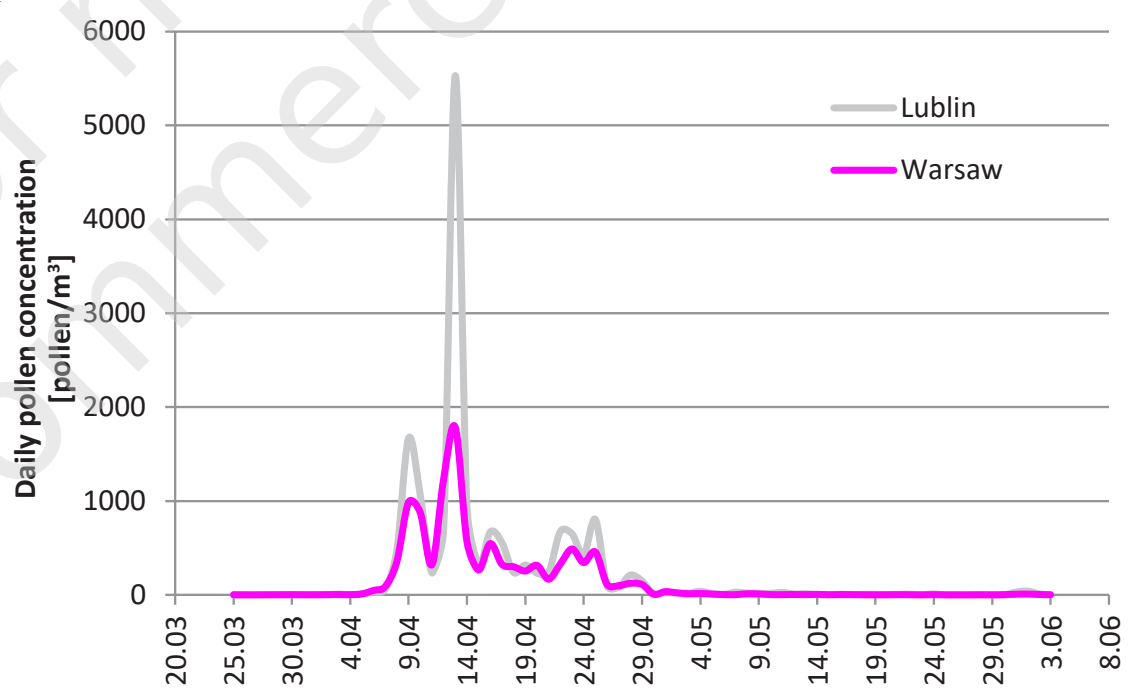

of the typical birch season starts [7], especially when the low variability of this season characteristic is taking into account. No unexpected birch pollen occurrence in Poland originating e.g. from the long-distance transport has been observed, as it was described many times by the other authors $[22,23]$.

The season characteristics of the highest variability were seasonal pollen integral and the maximum daily pollen concentration, which are characteristic for pollen seasons, including birch seasons [7]. Among the analysed seasons, the most outstanding seems to be the birch pollen season noted in Bialystok (north-eastern Poland), which started the latest (similarly as in Olsztyn, located close to Bialystok), lasted the longest and was the least intensive. In spite of that, temper- ature in March, in the north-eastern part of Poland was slightly higher in relation to the reference period (1981-2010) [21] the thermal conditions in this region were less favourable for trees pollination than in the other regions. Temperature isolines in early spring show a descending gradient of temperature from the south-western toward north-eastern direction, what is concurrent with the pollen season starts (e.g. in case of alder and hazel) [24].

\section{Conclusions}

- The birch pollen seasons in 2020 started at the selected sites in Poland in the first decade of April, expect at Olsztyn (April 11 $1^{\text {th }}$ ). 
Figure 4. Birch pollen concentration in Bydgoszcz and Piotrkow Trybunalski in 2020.

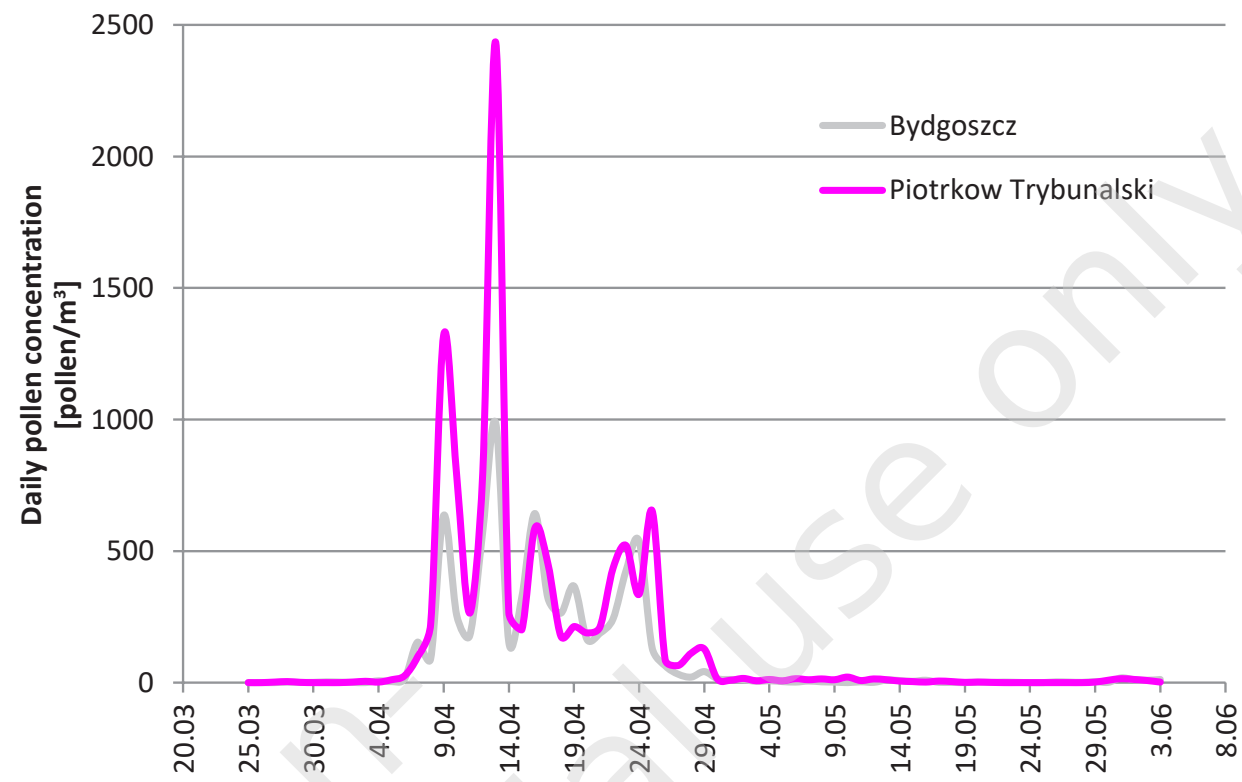

Figure 5. Birch pollen concentration in Szczecin and Zielona Gora in 2020.

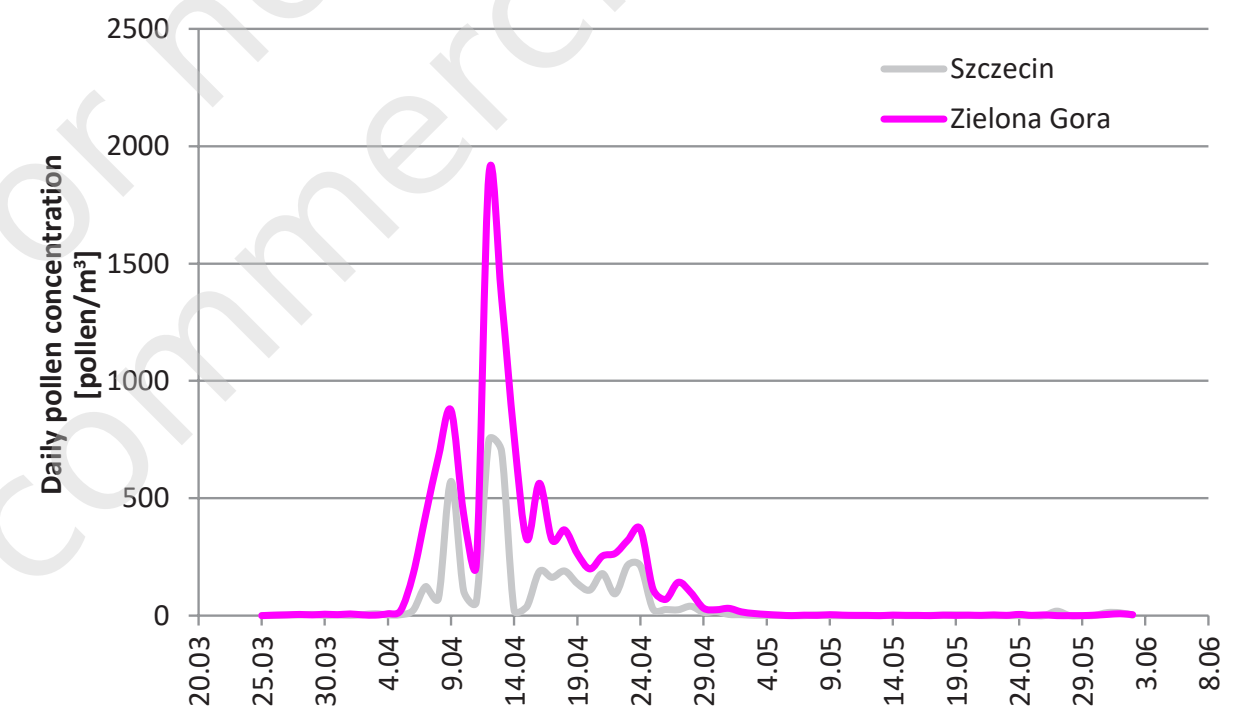

Figure 6. Birch pollen concentration in Olsztyn and Bialystok in 2020.

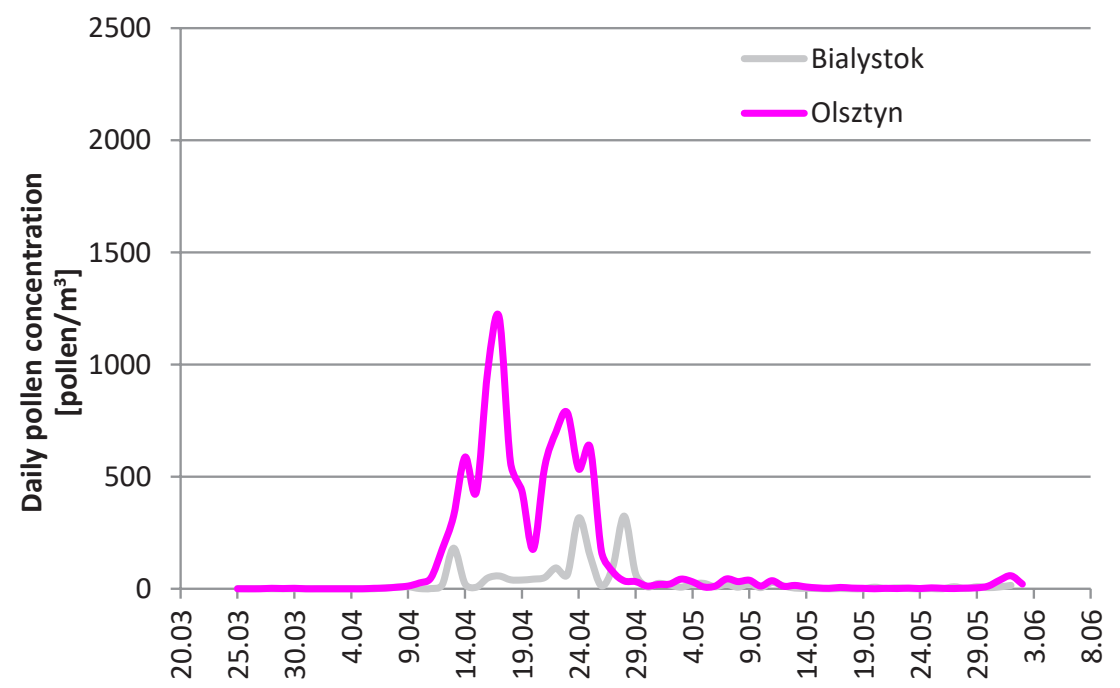


- The end of the birch pollen seasons was noted in the last decade of May.

- The daily concentration and annual pollen grains sum (SPIn) were the most variable season characteristics, reaching the highest values in Lublin.

- The annual birch pollen amount at 12 pollen stations in 2020 was lower than in 2019.

- The thermal conditions in the north-eastern part of Poland were the least favourable for birch pollen seasons.

\section{References}

1. Beck P, Caudullo G, de Rigo D et al. Betula pendula, Betula pubescens and other birches in Europe: distributions, habitat, usage and threates. In: San-Miguel-Ayanz J, de Rigo D, Caudullo G (ed) et al. European Atlas Forest Tree Speies. Publ Off EU., Luxembourg 2016: e010226+.

2. Seneta W, Dolatowski J. Dendrologia. Państwowe Wydawnictwo Naukowe PWN, Warszawa 2007.

3. Zając A, Zając $M$ (ed). Atlas rozmieszczenia roślin naczyniowych w Polsce: Dodatek. Distribution Atlas of Vascular Plants in Poland: Appendix. Instytut Botaniki Uniwersytetu Jagiellońskiego, Kraków 2019.

4. Biedermann T, Winther L, Till SJ et al. Birch pollen allergy in Europe. Allergy. 2019; 74: 1237-40.

5. D'Amato D, Cecchi L, Bonini $S$ et al. Allergenic pollen and pollen allergy in Europe. Allergy. 2007; 62(9): 976-90.

6. Myszkowska D. Prediction of the birch pollen season characteristics in Cracow, Poland using and 18-year data series. Aerobiologia. 2013, 29: 31-44.

7. Weryszko-Chmielewska E. Ziarna pytku i zarodniki grzybów w powietrzu różnych regionów Polski. Polskie Towarzystwo Botaniczne. Norbertinum, Lublin-Warszawa 2014.

8. Kubik-Komar A, Piotrowska-Weryszko K, Weryszko-Chmielewska $E$ et al. A study on the spatial and temporal variability in airborne Betula pollen concentration in five cities in Poland using multivariate analyses. Sci Total Environ. 2019; 660: 1070-8.

9. Małolepszy J, Liebhart J, Wojtyniak B et al. Występowanie chorób alergicznych w Polsce. Alerg Astma Immunol. 2000; 5(2): 163-9.

10. Samolinski B, Sybilski A, Raciborski F et al. Prevalence of rhinitis in Polish population according to the ECAP (Epidemiology of Allergic Disorders in Poland) study. Otolaryngol Pol. 2009; 63(4): 324-30.

11. Małolepszy J, Liebhart J, Wojtyniak B et al. Występowanie chorób alergicznych w Polsce. Alerg Astma Immunol. 2000; 5(2): 163-9.

12. Myszkowska D, Piotrowicz K. Birch (Betula L.) pollen seasons in Cracow in 1991-2008 associated to the meteorological conditions. Acta Agrobotanica. 2009; 62(2): 67-75.
13. Moverare R, Westritschnig $K$, Svensson M et al. Different IgE reactivity profiles in birch pollen-sensitive patients from six European populations revealed by recombinant allergens: an imprint of local sensitization. Int Arch Allergy Immunol. 2019; 128(4): 325-35.

14. Matricardi PM, Kleine-Tebbe J, Jürgen Hoffmann H (ed) et al. Molecular allergology. User's guide. The European Academy of Allergy and Clinical Immunology (EAACI). John Wiley \& Sons, Zurich 2016.

15. Galán C, Smith M, Thibaudon $M$ et al. Pollen monitoring: Minimum Requirements and Reproducibility of Analysis. Aerobiologia. 2014; 30: 385-95.

16. Galán C, Ariatti A, Bonini $M$ et al. Recommended terminology for aerobiological studies. Aerobiologia. 2017; 33(3): 293-5.

17. Piotrowska-Weryszko K, Weryszko-Chmielewska E, Dmitruk M et al. The analysis of Betula pollen season in Poland in 2019. Alergoprofil. 2019; 15(3): 10-5.

18. Dahl A, Galan C, Hajkova L. The onset, course and intensity ofthe pollen season. In: Sofiev M, Bergmann K-Ch (ed). Allergenic pollen. A review of the production, release, distribution and health impacts. Dordrecht: Springer. 2013; 29-70.

19. Myszkowska D. Predicting tree pollen season start dates using thermal conditions. Aerobiologia. 2014; 30(3): 307-21.

20. Laadi K. Regional variations in the pollen season of Betula in Burgundy: Two models for predicting the start of the pollination. Aerobiologia. 2001; 17: 247-54.

21. Linkosalo T, Ranta H, Oksanen A et al. A double-threshold temperature sum model for predicting the flowering duration and relative intensity of Betula pendula and B. pubescens. Agr Forest Meteorol. 2010; 150: 1579-784.

22. https://klimat.imgw.pl/pl/biuletyn-monitoring/\#2020/03.

23. Borycka K, Ortyl B, Kasprzyk I. Temporal variations and spatial differentiation inthe black alder and silver birch pollination pattern - the impact of local climate or something more? Agric For Meteorol. 2017; 247: 65-78.

24. Bogawski P, Borycka K, Grewling $E$ et al. Detecting distant sources of airborne pollen for Poland: Integrating back-trajectory and dispersion modelling with a satellite-based phenology. Sci Total Environ. 2019; 689: 109-25.

25. Myszkowska D, Jenner B, Puc M et al. Spatial variations in dynamics of Alnus and Corylus pollen seasons in Poland. Aerobiologia. 2010; 26(3): 209-21.

ORCID

M. Ziemianin - http://orcid.org/0000-0003-4568-8710

D. Myszkowska - http://orcid.org/0000-0002-1493-3990

M. Puc - hitp://orcid. org/0000-0001-6734-9352

A. Lipiec - http://orcid.org/0000-0003-3037-2326

M. Malkiewicz - http://orcid.org/0000-0001-6768-7968

K. Piotrowska-Weryszko - hitp:///orcid.org/0000-0003-3827-3218

G. Siergiejko - http://orcid org/0000-0003-4084-8332

E. Kalinowska - http://orcid.org/0000-0003-4821-6882

D. Jurkiewicz - http:///orcid.org/0000-0003-3729-2679 
A. Wieczorkiewicz - http://orcid.org/0000-0003-1705-2264

P. Rapiejko - http://orcid.org/0000-0003-3729-2679

Author's contributions:

Ziemianin M.: 50\%; Myszkowska D.: 10\%; other authors: $4 \%$ per each.

Conflict of interests:

The authors declare that they have no competing interests.

Ethics:

The contents presented in this paper are compatible with the rules the Declaration of Helsin$\mathrm{ki}$, EU directives and standardized requirements for medical journals.

Copyright: (C) Medical Education sp. z 0.0. This is an Open Access article distributed under the terms of the Attribution-NonCommercial 4.0 International (CC BY-NC 4.0). License (https://creativecommons.org/licenses/by-nc/4.0/), allowing third parties to copy and redis- tribute the material in any medium or format and to remix, transform, and build upon the material, provided the original work is properly cited and states its license.

\section{Correspondence:}

\section{Monika Ziemianin}

Jagiellonian University Medical College,

Department of Clinical and Environmental Allergology 31-503 Cracow, Botaniczna 3

phone: +48 124248987 (87 98)

e-mail: monika.wandas@uj.edu.pl

(c) Medical Education. For private and non-commercial use only. Downloaded from https://www.journalsmededu.pl/index.php/alergoprofil: 26.04.2023; 13:33,55 